Youth access

\section{It is time to abandon youth access tobacco programmes}

\section{P M Ling, A Landman, S A Glantz}

\section{Youth access has benefited the tobacco industry}

7 he most widespread and popular strategy for reducing tobacco use has been "youth access" laws, which make it illegal to sell cigarettes to teenagers. In the USA, youth access controls have been part of tobacco control policies required by the federal government in order to obtain funding for substance abuse programmes ${ }^{1}$; they were at the core of the tobacco regulation proposed by the Food and Drug Administration ${ }^{2}$ and struck down by the US Supreme Court. Both the US Centers for Disease Control and Prevention ${ }^{3}$ and the Institute of Medicine $e^{4}$ recommend youth access controls as part of a comprehensive tobacco control program. By August 2001, in the USA all 50 states and 1139 local governments had passed youth access laws (American Nonsmokers' Rights Foundation database, 24 August 2001).

Unfortunately, while these programmes do make it difficult for teens to purchase cigarettes, ${ }^{5-7}$ on the whole they do not affect teen smoking prevalence ${ }^{8}$ (fig 1). Proponents of youth access programmes have argued that this approach would be effective, if only the programmes were "done right" and successfully prevented a high proportion of youth from using commercial sources to buy cigarettes, ${ }^{9}$ and that exceeding a high hypothesised threshold ${ }^{8}$ (fig 1). sources of cigarettes. "threshold" level of merchant compliance $^{9-14}$ is necessary to affect youth smoking. There is no consistent empirical evidence to support the existence of this

The paper by Jones and colleagues ${ }^{15}$ in this issue of Tobacco Control explains why enforcement of youth access laws does not affect teen smoking. Using data from the Youth Risk Behavior Survey to describe the usual sources of cigarettes for high school student smokers, they found that in addition to purchasing cigarettes from stores, students give others money to buy cigarettes, borrow cigarettes from others, and sometimes steal them or use vending machines. ${ }^{15}$ From 1995 to 1999, significantly fewer student smokers purchased cigarettes in stores, while significantly more gave others money to buy cigarettes. ${ }^{15}$ Consistent with earlier studies, ${ }^{13} 141617$ they $^{15}$ conclude that as youth access laws make it harder to purchase cigarettes, teens simply use other means to get cigarettes. They conclude, correctly, that the effectiveness of tobacco access laws are undermined by these other "social sources" of cigarettes. They recommend stricter enforcement of tobacco access laws and interventions to reduce social

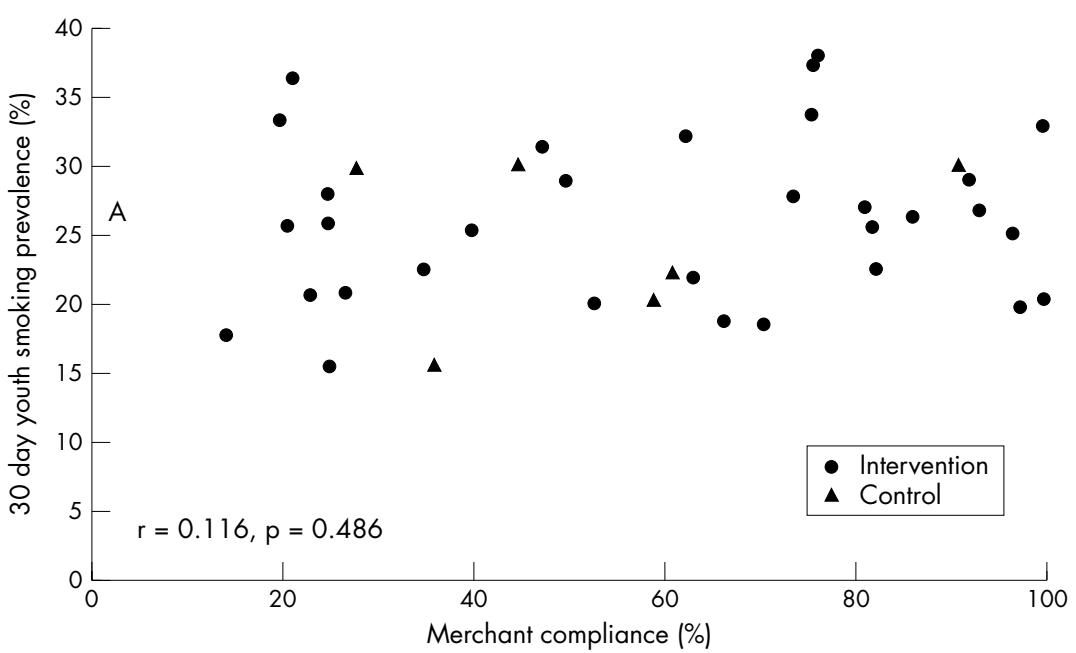

Figure 1 This graph shows the relation between 30 day teen smoking prevalence and the level of merchant compliance with youth access regulations in different communities. There is no relation between teen smoking prevalence and the level of merchant compliance with youth access policies. There is no evidence of a threshold effect. From Fichtenberg and Glantz ${ }^{8}$, with permission of the publisher. (See paper for more details on methodology.)
This recommendation is bad policy for four reasons. Firstly, there is no consistent evidence that increased enforcement of youth access laws affects youth smoking $^{8}$ (fig 1). These results are not surprising because, although most smokers start experimenting with cigarettes in their teens, few teens smoke daily. Indeed, the majority of teen smokers are "experimenters" who have smoked less than 100 cigarettes in their lifetime. ${ }^{18}$ It is virtually impossible to locate and target the few cigarettes needed to drive these irregular light smoking patterns. Secondly, trying to restrict "social sources" of cigarettes is impractical, blames children, their friends and parents, may lead to laws criminalising children for possession of cigarettes, ${ }^{19}$ and further diverts attention from tobacco industry marketing practices. Indeed, Philip Morris has embraced this tactic, and is actively promoting messages telling parents to keep their cigarettes away from their kids. ${ }^{20}{ }^{21}$ Thirdly, this message is unlikely to resonate with teens, since one of the strongest perceived benefits of smoking is using cigarettes as a way to connect with others, particularly in the face of opposition. ${ }^{22}$ Fourthly, and most important, there is no evidence to suggest that trying to restrict social sources of cigarettes would work any better at reducing teen smoking prevalence than restricting commercial access.

It has been argued that even if they do not affect youth smoking prevalence, youth access programmes are valuable because they are politically safer than policies involving clean indoor air or anti-tobacco media campaigns, and that they engage the public and help build coalitions for tobacco control. ${ }^{53}$ While this may be true for tobacco control advocates, it is even more true for the tobacco industry.

\section{RETAILER TRAINING TO FIGHT TOBACCO CONTROL}

Retailer training programmes focusing on youth access have facilitated tobacco industry development of a badly needed network at the local level to help defeat tobacco control efforts. This network has provided the industry with an extensive "early warning" network to identify emerging threats of the full range of tobacco control policies. ${ }^{24-26}$

By 1992 the Tobacco Institute was using its "It's the Law" programme (fig 2), which nominally trained retailers to ask purchasers for identification, alongside its efforts to urge retailers to monitor for local tobacco control efforts, including self service cigarette display bans and public smoking restrictions, so the Tobacco Institute could mobilise them to fight these tobacco control efforts: "For monitoring purposes, we [the Tobacco Institute] fund 
our allies in the convenience store groups to regularly report on ordinance introductions and assist in campaigns to stop unreasonable measures ... Promotion of The Institute's "It's the Law" programme and other industry programmes play a helpful role was well."24

Philip Morris took over the "It's the Law" programme in 1994. A 1994 speech by Ellen Merlo, senior vice president of corporate affairs at Philip Morris, details how alliances with local retailers allowed the industry to fight legislation: " . . with . . .local activity rampant, we realized we had to have some way to control the bleeding. We needed an effective system to let us know when and where local laws were being proposed, either at town meetings, in the local city councils or by Boards of Health. Working with the New England Convenience Store Association and other tobacco companies, we developed a network whereby local retailers could assist us by providing information on legislative activities in every Massachusetts Community. We've discovered that if we have enough advance notice to do some homework and get somebody there for the public hearing, we can make a difference.".25

The convenience stores also provide coverage for the industry to fight a wide range of effective tobacco control policies, including clean indoor air. ${ }^{27}$ For example, in Ohio, Philip Morris gained endorsements from the Ohio Grocers Association, the Ohio Association of Convenience Stores, the Ohio Petroleum Retailers and Repair Association, and the Ohio Petroleum Marketers Association for its "Ask First/It's the Law" programme. ${ }^{28}$ These organisations later provided Philip Morris $^{29}{ }^{30}$ cover for working to pass a law preempting the ability of local boards of health to enact smoke free workplace and restaurant regulations. ${ }^{31}$ When this legislation was proposed in the state legislature in 1995, the restrictions on local

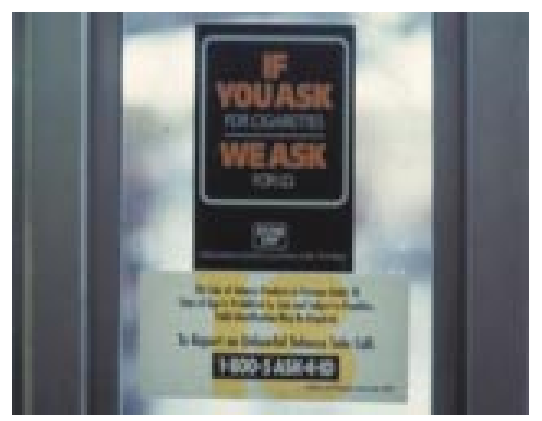

Figure 2 Photograph of entrance to convenience store in California showing side-by-side comparison of tobacco industry "It's the Law" youth access notification and a corresponding notification from the California Department of Health Services. The messages are indistinguishable. Indeed, the tobacco industry message is clearer and stronger than the one from the Health Department. boards of health were hidden in what appeared to be primarily youth access legislation, entitled "The Comprehensive Smoking Regulation and Prevention of Youth Access to Tobacco Act of 1995". ${ }^{32}$ The Ohio Council of Retail Merchants, the Ohio Grocers Association, the Ohio Association of Convenience Stores, the Ohio Petroleum Retailers and Repair Association, and the Ohio Petroleum Marketers Association joined with restaurant, licensed beverage, and vending associations supporting this bill, while tobacco companies avoided mention. ${ }^{30} 3133$ Philip Morris also drafted letters and phone scripts to contact individual retailers urging them to write their legislators to support this bill..$^{34-37}$ The bill was defeated, but reappeared in 2001, when the primary public support for a bill restricting health boards' ability to make local smoking policies was the Ohio Council of Retail Merchants. ${ }^{38}$ The tobacco industry stayed out of the public eye, and politicians supporting Philip Morris' bill claimed they were simply supporting merchants. ${ }^{39-42}$

\section{OTHER BENEFITS TO THE TOBACCO INDUSTRY}

Youth access programmes have also been widely supported by the tobacco industry, ${ }^{43}$ perhaps because they reinforce the industry's key marketing message that "smoking is for adults", which arguably makes smoking even more attractive to teens. ${ }^{44}$ The industry has widely publicised its own youth access programmes, such as "It's the Law", "We Card", and "Action Against Access". Some ${ }^{54}$ have argued that the industry programmes are "bad" in comparison with the "good" programmes run by health groups because they do not include vigorous enforcement efforts. To the general public, however, these programmes are indistinguishable (fig 2).

These programmes have helped the industry fight effective tobacco control legislation and educational programmes by creating the illusion that they are doing something. They can also bolster industry credibility. Philip Morris has monitored the effect of their "Action Against Access" programme on smokers' awareness that Philip Morris started the programme, and how the programme affected consumers' feelings about their company. ${ }^{46-48}$ Philip Morris's 1995 "Talking points to key customers on youth issue" emphasises how Philip Morris could benefit in the long term if it took the lead in addressing the sensitive "youth access" issue: "If we can frame proactive legislation or other kinds of actions on the Youth Access issue, if we can get out in front on this issue now, if we can seize the moral high ground, we will not only be doing the right thing, we will be protecting our industry for decades to come ${ }^{49}$ [emphasis in original].

A 1991 Tobacco Institute discussion paper noted: "Broad-based advertising [of industry youth programmes] ... has the important effect of making the public aware that the industry says it is trying to do the right thing ..." ${ }^{150}$

The tobacco industry's vocal support of youth access programmes is similar to tobacco industry "accommodation" campaigns in response to pending clean indoor air laws. ${ }^{27}$ Accommodation campaigns aim to convince decision makers that legislation (such as smoke-free bars or restaurants) is unnecessary because establishments can take voluntary action to accommodate smokers and nonsmokers. ${ }^{27}$ The accommodation message allows the tobacco industry to take a political stance that appears reasonable: "we want to accommodate both smokers and non-smokers" and that makes health advocates appear extreme when advocating for clear indoor air. Similarly, youth access programmes allow the tobacco industry to appear to want to discourage youth smoking, thus seizing the "political centre" and "forcing health advocates to the extreme"..$^{50}$ In fact, the Tobacco Institute strategy planned to "bait antitobacco forces to criticize industry efforts" and "focus media on anti's extremism". ${ }^{50}$ The suggestions by Jones and colleagues ${ }^{15}$ and others ${ }^{514}$ to try to stop teens from obtaining cigarettes from their friends or parents will be even easier for the industry to paint as "extreme".

In addition to using youth access programmes to fight more effective policies, the tobacco industry has reaped several other benefits. Tobacco industry youth access messages (which do not contradict cigarette advertising) have allowed the industry to create competition with other media campaigns (such as the "Truth" campaign which exposes tobacco industry manipulation of teens) which actually affect teen smoking prevalence. ${ }^{51-55}$

\section{CONCLUSION}

At best, youth access programmes are ineffective and a drain on limited resources. Even if they did affect youth smoking, the impact on smoking prevalence and morbidity and mortality from smoking would not be seen for decades. ${ }^{56}$ At worst, they are counterproductive and help the tobacco industry fight meaningful tobacco control policy. While youth access programmes seemed logical and well meaning, the simple fact is that they do not work and are now leading into even more futile efforts to control "social sources" of cigarettes.

It is time for public health practitioners to recognise that the balance of empirical evidence shows that youth access is a failed strategy and abandon it. Youth access should be removed from recommendations for comprehensive tobacco control programmes. Instead, tobacco control advocates should pursue 
strategies which have solid empirical evidence of effectiveness, such as smoke-free workplaces and homes, ${ }^{57-60}$ taxes, ${ }^{57-596162}$ media campaigns, ${ }^{63}$ and secondhand smoke messages. ${ }^{64}$

\section{ACKNOWLEDGEMENT}

This work was supported by NIH Grant T32 MH-19105 and National Cancer Institute Grant CA-87472.

Tobacco Control 2002;11:3-6

\section{Authors' affiliations}

P M Ling, A Landman, S A Glantz, Center for Tobacco Control Research and Education, Institute for Health Policy Studies,

Cardiovascular Research Institute, Center for

AIDS Prevention Studies, University of

California, San Francisco, California, USA

Correspondence to: Stanton A Glantz, PhD, Professor of Medicine, Box 0130, University of California, San Francisco, CA 94143, USA glantz@medicine.ucsf.edu

\section{REFERENCES}

1 US Department of Health and Human Services. Substance abuse prevention and treatment block grants: sale or distribution of tobacco products to individuals under 18 years of age (45 CFR Pt. 96). Federal Register 1993; 58:45156-74.

2 Food and Drug Administration. Regulations restricting the sale and distribution of cigarettes and smokeless tobacco products to protect children and adolescents. Federal Register 1995

3 Centers for Disease Control and Prevention. Best practices for comprehensive tobacco control program - August 1999. Atlanta, Georgia: US Department of Health and Human Services, Centers for Disease Control and Prevention, Office on Smoking and Health, August 1999.

4 Institute of Medicine. State programs can reduce tobacco use. Washington DC: National Cancer Policy Board, Institute of Medicine, National Research Council; 2000. www.nap.edu.

5 Forster JL, Wolfson M. Youth access to tobacco: policies and politics. Ann Rev Public Health 1998; 19:203-35

6 Lantz P, Jacobson P, Warner K, et al. Investing in youth tobacco control: a review of smoking prevention and control strategies. Tobacco Control 1999;9:47-63.

7 Stead L, Lancaster T. A systematic review of interventions for preventing tobacco sales to minors. Tobacco Control 2000;9: 169-76.

8 Fichtenberg CM, Glantz SA. Youth access interventions do not affect youth smoking. Pediatrics (in press).

9 Difranza JR. Youth access: the baby and the bath water [editorial]. Tobacco Control 2000;9:120-1.

10 Rigotti N, DiFranza J, et al. The effect of enforcing tobacco-sales laws on adolescents' access to tobacco and smoking behavior. $N$ Engl J Med 1997;337:1044-51.

11 Jason L, Ji PY, Anes MD, et al. Active enforcement of cigarette control laws in the prevention of cigarette sales to minors. JAMA 1991;266:3159-61.

12 Difranza JR, Carlson RP, Caisse RE. Reducing youth access to tobacco. Tobacco Control 1992;1:58.

13 Forster J, Murray D, Wolfson M, et al. The effects of community policies to reduce youth access to tobacco. Am J Public Health 1998:88:1193-8.

14 Difranza JR, Coleman M. Sources of tobacco for youths in communities with strong enforcement of youth access laws. Tobacco Control 2001;10:323-8.

15 Jones SE, Sharp DJ, Husten CG, et al. Cigarette acquisition and proof of age among
U.S. high school students who smoke. Tobacco Control 2002;11:20-5.

16 Cummings KM, Hyland A, Perla J, et al. Does increasing retailer compliance with a minor's access law reduce youth smoking? Nicotine \& Tobacco Research (in press).

17 Hinds M. Impact of local ordinance banning tobacco sales to minors. Public Health Rep 1992;82:355-8.

18 American Legacy Foundation. First Look Report 3. Pathways to established smoking: results from the 1999 National Youth Tobacco Survey: American Legacy Foundation, October 2000.

19 Canadian Cancer Society. Youth tobacco posession laws policy analysis. Ottawa: Canadian Cancer Society; September 2001

20 Philip Morris Tobacco Company. Youth access prevention message points $2 / 18 / 00$ Philip Morris Tobacco Company. February 18, 2000. Access date: December 7, 2001 Bates No. 2071788874-8879. URL: www.pmdocs.com. actual ads Bates No. 2071788856/8857/8862/8863/8902/ 8903.

21 Philip Morris USA. Youth smoking prevention - access prevention: Philip Morris, USA 2001. Access date: December 7, 2001. URL: http://www.pmusa.com/ DisplayPageWithTopic. asp? ID $=79$

22 Hugh Bain Research. The psychology and significant moments and peak experiences in cigarette smoking. British American Tobacco Company. November, 1993. UCSF Tobacco Control Archives. Access date: April 16, 2001. Bates No. 500237804-7890. URL: www.library.ucsf.edu/tobacco

23 Myers ML. Adults versus teenagers: a false dilemma and a dangerous choice. Tobacco Control 1999;8:336-8.

24 Malmgren K, Chicolte S. Draft local program. Tobacco Institute. November 30, 1992. Philip Morris Documents Website. Access date: December 7, 2001. Bates No. 2023959567-9579. URL: www.pmdocs.com. cover letter is Bates No. 2023959566.

25 Merlo E. No title [Speech given by Ellen Merlo]. Philip Morris Tobacco Company. October 24, 1994. Access date: November 13, 2001. Bates No. 2040236685-6706 URL: www.pmdocs.com.

26 Walls T, Daragan K, Pontarelli J. CAC presentation \#4. Philip Morris Tobacco Company. July 8, 1994. Access date: December 6, 2001. Bates No.

2041183751-3790. URL: www.pmdocs.com.

27 Dearlove JV, Glantz SA. Boards of health as venues for clean indoor air policymaking. Am J Public Health (in press).

28 Chaikin K. Ask First/It's the Law case history support. Philip Morris Tobacco Company. February 22, 1995. Access date: December 6, 2001. Bates No. 2044336791-6800. URL: www.pmdocs.com.

29 Author unknown. No title ?presentation by Jim Pontarelli, Karen Daragan on accommodation/preemption programs]. Philip Morris Tobacco Company. [PM filing under June 30 but document pages are dated] July 8, 1994. Access date: December 6, 2001. Bates No. 2040235925-5945. URL: www.pmdocs.com.

30 Author unknown. Organizations in support of House Bill 299. Philip Morris Tobacco Company. March 26, 1996. Access date: December 6, 2001. Bates No.

2063422603-2604. URL: www.pmdocs.com.

31 Riskind J, Bradshaw J. Tobacco forces, foes to butt heads on smoking. The Columbus Dispatch 1995 February 4; Local and National News Section, p1C.

32 Philip Morris. An important message about your board of health. Philip Morris. 1995. Access date: December 3, 2001 . Bates No. 2063417286-7294. URL: www.pmdocs.com.

33 The Hannah Report. "Under 18 No Tobacco" program commences. Philip Morris Tobacco Company. August 13, 1996. Access date: December 6, 2001. Bates No. 2062905640-5641. URL: www.pmdocs.com.

34 Johnson C. Ohio preemption/major accounts. Philip Morris Tobacco Company.
July 31 1995. Access date: December 6 2001. Bates No. 2047589862-9865. URL: www.pmdocs.com. Master ID (set of 3 related letters) is $2047589861 / 9868$

35 Willard HA. Priority letter [letter urging writing elected officials supporting HB299]. Philip Morris Tobacco Company. October 25 1995. Access date: December 6, 2001. Bates No. 2047593603-3604. URL:

www.pmdocs.com.

36 RTC Direct. Ohio Retailers Program background information. Philip Morris Tobacco Company. January 5, 1996. Access date: December 6, 2001. Bates No. 2047593563-3566. URL: www.pmdocs.com

37 RTC Direct. Ohio Phone program universe: H.B. 299 non responders. Target: State legislators. Philip Morris Tobacco Company. January 3, 1995. Access date: December 6, 2001. Bates No. 2047593586/3587. URL: www.pmdocs.com

38 Welsh-Huggins A. Lawmakers try again to stop health boards from banning smoking. The Associated Press State \& Local Wire, 11 October 2001

39 Bischoff LA. Panel suggests counties butt out; Bill would remove health boards' power. Dayton Daily News 25 October 2001; City Edition; online source.

40 Brown TC. Tobacco industry sniffs whiff of success; Bill to alter how health boards regulate product. The Plain Dealer 22 October 2001; B1 Metro Section.

41 Smyth JC. Legislators push to take health officials' power to ban smoking in public places. The Plain Dealer 14 October 2001 online source.

42 Starr C. Anti-smoking laws under scrutiny. The Cincinnati Post 2001; News section, online source.

43 Levy C. Smoking by young people. Philip morris USA also wants to reduce incidence of smoking by young people. BM 1999:319:1268-9.

44 Glantz SA. Preventing tobacco use-the youth access trap [editorial]. Am J Public Health 1996;86:156-8

45 DiFranza JR, Savageau JA, Aisquith BF. Youth access to tobacco: the effects of age, gender, vending machine locks, and "it's the law" programs. Am J Public Health. 1996;86:221-4

46 Author unknown. AAA measurement methodologies. Philip Morris Tobacco Company. 1995. Access date: September 15 2000. Bates No. 2045191320. URL: www.pmdocs.com.

47 Author unknown. Action against access. Philip Morris Tobacco Company. August 15-November 26, 1995. Access date: July 9, 2001. Bates No. 2045191191-1315. URL: www.pmdocs.com

48 Author unknown. Action against access module. Philip Morris Tobacco Company. August 15, 1995. Access date: July 9, 2001 Bates No. 2045191316-1318. URL: www.pmdocs.com

49 JGR, [document sent from Ellen Merlo]. $\mathrm{WIC} / \mathrm{JJM} / \mathrm{MES}$ Talking points to key customers on youth issue. Philip Morris Tobacco Company. January 19, 1995 Access date: December 6, 2001. Bates No. 2042761477-1486. URL: www.pmdocs.com cover letter is 2042761476

50 Author unknown. Discussion paper. Tobacco Institute. January 29, 1991. Access date: December 6, 2001. Bates No. TIMN0 164422-4424. URL: www.tobaccoinstitute.com

51 Sly DF, Heald GR, Ray S. The Florida "truth" anti-tobacco media evaluation: design, first year results, and implications for planning future state media evaluations. Tobacco Control 2001;10:9-15

52 Sly DF, Hopkins RS, Trapido E, et al. Influence of a counteradvertising media campaign on initiation of smoking: the Florida "truth" campaign. Am J Public Health 2001;91:233-8

53 Haviland ML. Comparison of Legacy's truth with the Philip Morris Campaign. Abstrac presented at the American Public Health Association annual meeting, 2001 
54 Moon-Howard J, Arnold E, Haviland ML. Assessing the efficacy of anti-smoking messages for urban youth at risk: a comparison of the American Legacy Foundation and Philip Morris ad campaigns. Abstract presented at the American Public Health Association annual meeting, 2001

55 Farrelly M, Healton C, Davis K. Truth and videotapes: reactions to truth campaign ads by smoking status. Abstract presented at the American Public Health Association annual meeting, 2001

56 Levy DT, Cummings KM, Hyland A. A simulation of the effects of youth initiation policies on overall cigarette use. Am J Public Health 2000;90:1311-4.

57 Chaloupka F, Pacula R. Sex and race differences in young people's responsiveness to price and tobacco control policies. Tobacco Control 1999;8:373-7.

58 Chaloupka F, Wechsler H. Price, tobacco control policies, and smoking among young adults. Journal of Health Economics 1997; 16:359-73

59 Chaloupka F, Grossman M. Price, tobacco control policies and youth smoking. NBER Working Paper Series. 1996; 5740.

60 Wakefield M, Chaloupka F, Kaufman N, et al. Effect of restrictions at home, at school, and in public places on teenage smoking: cross sectional study. BM 2000;321:333-7

61 Wasserman J, Manning W, Newhouse J, et al. The effects of excise taxes and regulations on cigarette smoking. Journal of Health Economics 1991;10:43-64.
62 US Department of Health and Human Services. Reducing tobacco use: a report of the Surgeon General. Atlanta, Georgia: US Deparment of Health and Human Services, Centers for Disease Control and Prevention National Center for Chronic Disease Prevention and Health Promotion, Office of Smoking and Health, 2000.

63 Bauer U, Johnson T. 2000 Florida Youth Tobacco Survey results. Tallahassee, Florida: Florida Department of Health, Bureau of Epidemiology; 1 March 2000

www.state.fl.us/tobacco.

64 Glantz SA, Jamieson P. Attitudes toward secondhand smoke, smoking, and quitting among young people. Pediatrics 2000; 106:E82.

\section{AD WATCH}

"Bursting with cancer!" Vacuous marketing slogans from around the world

\section{Our events promote more than just our brands.}
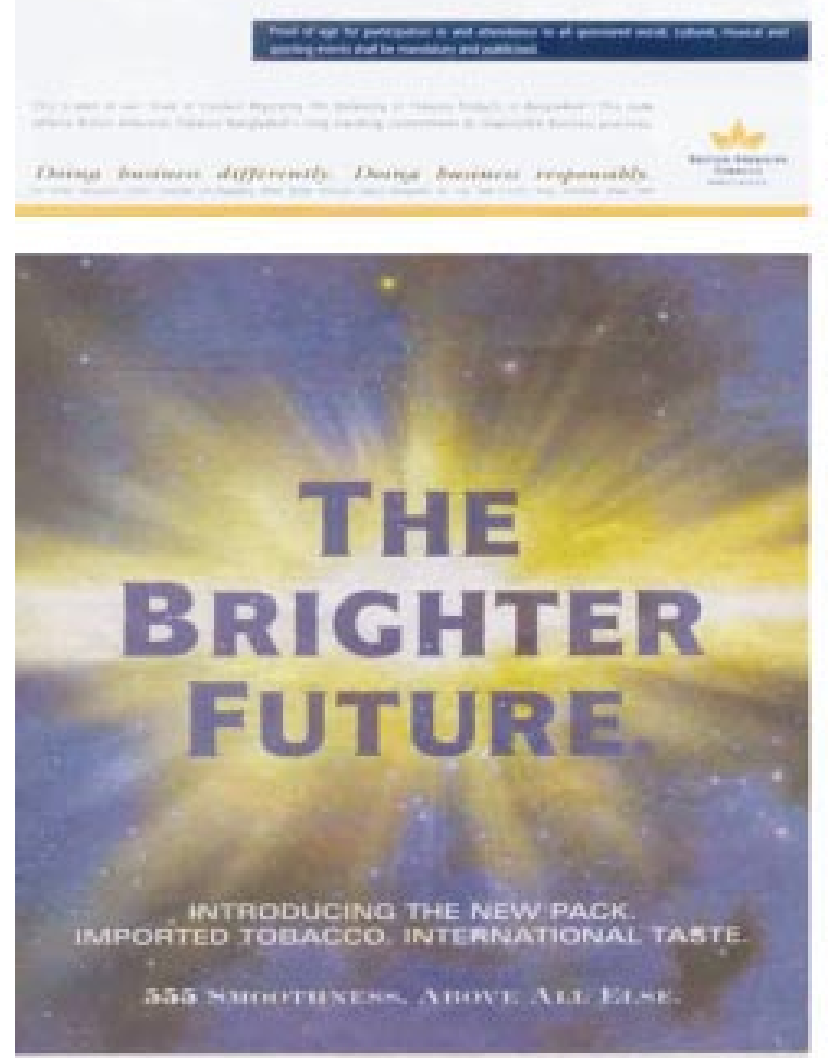

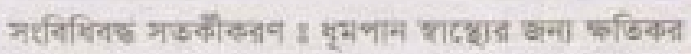

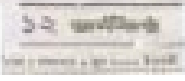

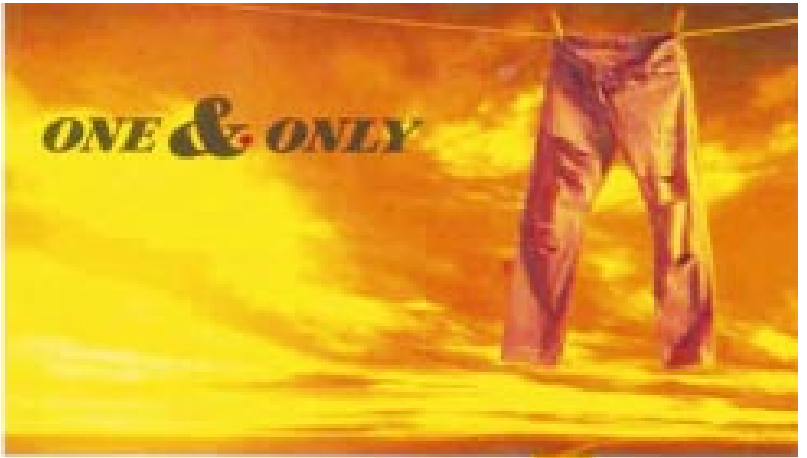

BE GOLD. RENSON A HEDGES
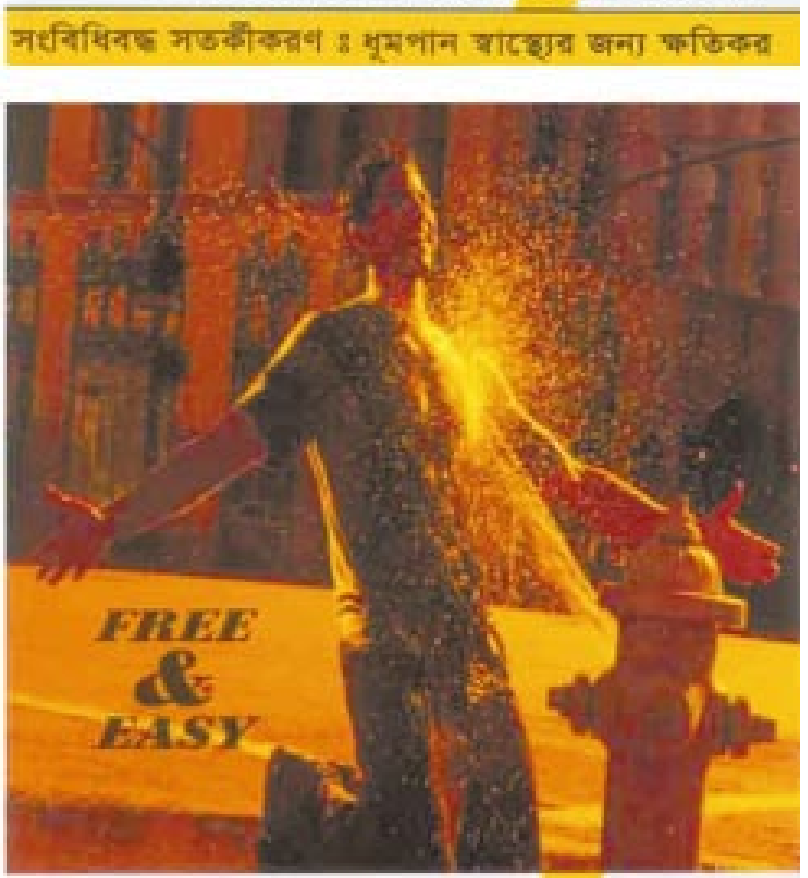

BE GOLD. BENSOV A HEDGES

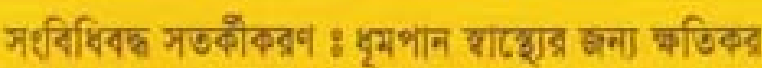

